\title{
The Relationship between Vocational Personality Types and Vocational Values*
}

\author{
Gürcan Şeker ${ }^{1}$, Burhan Çapri ${ }^{2}$ \\ ${ }^{1}$ Faculty of Education, Educational Science Department, Niğde Ömer Halisdemir University, Niğde, Turkey \\ ${ }^{2}$ Faculty of Education, Educational Science Department, Mersin University, Mersin, Turkey \\ Correspondence: Gürcan Şeker, Faculty of Education, Educational Science Department, Niğde Ömer Halisdemir \\ University, Niğde, Turkey.
}

Received: August 26, 2019

doi:10.11114/jets.v7i11.4478
Accepted: September 12, $2019 \quad$ Online Published: September 19, 2019

URL: https://doi.org/10.11114/jets.v7i11.4478

\begin{abstract}
In this study, the relationship between high school students' vocational personality types and vocational values was examined. The study data were collected from 488 high school students going to schools in Niğde city center. In the study, Vocational Personality Types Inventory and Vocational Value Inventory were administered. Canonical correlation analysis technique was used to analyze the data. The study results revealed that the canonical model was significant, and when the data on canonical functions were evaluated separately, three canonical functions were found significant. The common variance shared between the data sets of the canonical variables showing that there was a significant relationship between occupational personality types and occupational values were $44 \%$ for the first canonical function, $30 \%$ for the second canonical function and $11 \%$ for the third canonical function, respectively. The findings were discussed in the light of the related literature.
\end{abstract}

Keywords: vocation, vocational personality type, vocational value, high school students

\section{Introduction}

Career development is a lifelong process based on choosing amongst many occupations found in the community and being ready to continue life with these choices. During this process, each individual is affected by many factors such as family, personal values, abilities and social context (Brown, 2002).

Effective in career development process, factors like vocational interest (Ackerman, \& Beier, 2003; Deniz, 2009; Koç, 2006; Larson, \& Borgen, 2002; Logue, Lounsbury, Gupta, \& Leong, 2007; Y1lmaz, 2011) and vocational value (Atli, 2012; Berings, De Fruyt, \& Bouwen, 2004; Demircioğlu, 2004; Lewis, \& Hardin, 2002; Owen, Acar, Demir, Haskan, \& Kabalc1, 2009; Sortheix, Dietrich, Chow, \& Salmela-Aro, 2013) are frequently encountered in the literature.

Vocational interest is one of the basic structures of career development (Betsworth, \& Fouad, 1997). There are many definitions of the concept of vocational interest in the literature. For example, Strong (1960) described interests as activities that the individual liked and disliked, whereas Kuder (1977) defined interests as specifying the activities the individual wanted to prefer clearly (cited in Mount, Barrick, Scullen, \& Rounds, 2005). Moreover, Savickas (2013) stated that interests played an important role for the child to gain and develop respectability in his or her family, school and environment.

On the other hand, Holland (1973) took the concept of vocational interest to a different dimension. Holland stated that if vocational interests were interpreted as an expression of personality, the individual's activities, hobbies and preferences at work and at school could be seen as an expression of personality, in other words, "vocational interest was another aspect of personality. In this respect, he argued that interest inventories could also be seen as personality inventories (cited in Hogan, \& Blake, 1999). Holland (1997) also argued that that there were six personality types representing vocational interests and six vocational environments in parallel with these six personality types. Each individual was characterized by one of six vocational personality types: Realistic, Investigative, Artistic, Social, Enterprising and Conventional.

\footnotetext{
* This study was presented as an oral presentation at the $4^{\text {th }}$ International Eurasian Educational Research Congress held between 11-14 May, 2017 at Denizli.
} 
In Holland's theory, environmental profiles show parallelism with personality profiles. Therefore, the theory also evaluates individual-environment unity and tests the assumptions that are important for vocational development. The psychological distance between any two environmental or personality types is calculated according to the distance between similar and different personality types on the hexagon (see figure 1) (Gottfredson, \& Richards, 1999).

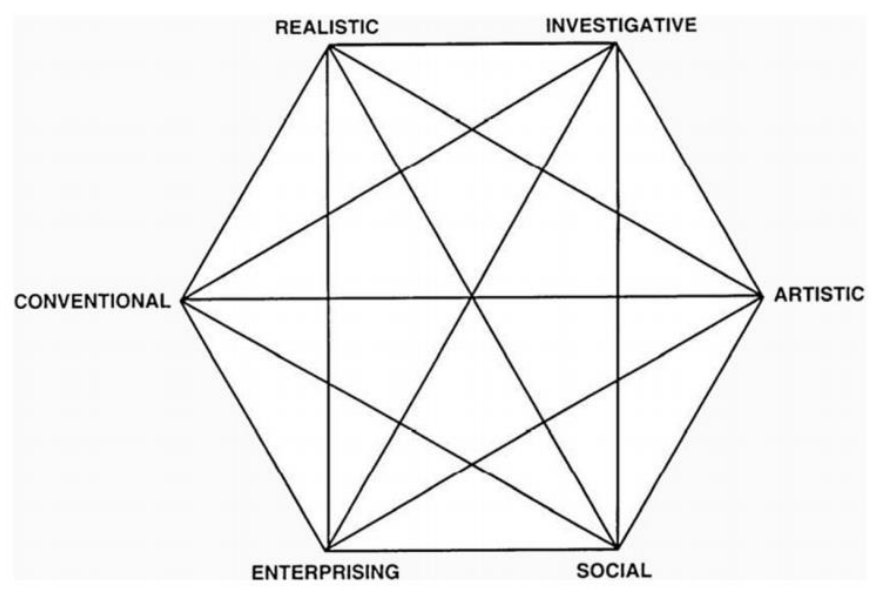

Figure 1. Holland hexagon model (Holland, 1997)

When the literature on studies based on Holland's vocational personality types are examined, there are studies testing the model in different cultures (Farth, Leong, \& Law, 1998; Ferreira, \& Hood, 1995), and making comparisons with different vocational interest models (Rounds, Davison, \& Dawis, 1979; Tracey, \& Rounds, 1993; Weinrach, 1996). In addition, there are also studies on the relationships between vocational personality types and variables such as sex (Anderson, Tracey, \& Rounds, 1997; Ryan, Tracey, \& Rounds, 1996) and personality traits (Larson, \& Borgen, 2002; Mount et al., 2005; Tokar, \& Swanson, 1995). Furthermore, Holland-based scale development-adaptation studies (Atli, \& Keldal, 2017; Ferreira, \& Hood, 1995; Perkmen, \& Tezci, 2015; Y1lmaz, 2011) are frequently encountered in the literature.

Another factor influencing the choice of vocation is vocational values. Values are a very comprehensive concept defined in various ways in various disciplines. However, like attitudes, needs, norms, interests and other individual characteristics, values are also considered as psychological structures that affect the individual's adaptation process (Hartung, 2006). Many career development theorists have developed different definitions and classifications about the concept of vocational value. Super (1970) defined vocational value as the importance of satisfaction sources obtained from a job for the individual, while Dawis and Lofquist (1984) considered it as conceptualization of latent or defined needs (cited in Rounds, \& Jin, 2012). With Brown's 'value-based vocational development theory' interest in vocational value began to increase in the mid-1990s. According to him, vocational value is the satisfaction obtained from a vocation (Brown, 2003). Schein (2006), in what he calls 'career anchor' approach, defined career value as concept of self comprised of individual's perceived the ability, interest and basic values and the total of his or her needs. Kuzgun (2009), on the other hand, conceptualized the vocational value in terms of the tasks that the occupations require and what the opportunities provided by the occupations meant for the individual.

The studies on vocational values in the literature reveal that researcher focused on vocational values of high school students (Atli, \& Kaya, 2016; Batur, 2014; Bayrakdar, 2009; Demircioğlu, 2004; Dick, \& Rallis, 1991) and university students (Bozgeyikli, Derin, \& Toprak, 2016; Burke, 1994; Koca, 2009, 2010; Moore, 2006). In addition, in the literature, there are also studies examining the vocational values according to sex (Beutell \& Brenner, 1986; Murphy, 2000) and according to different theories (Adıgüzel, \& Erdoğan, 2014; Nordvik, 1996). Some studies examined the relationships between personality traits and vocational values (Berings, De Fruyt, \& Bouwen, 2004; Hirschi, 2008).

When the literature on the relationship between vocational personality types and vocational values is examined, it is found that these studies are conducted with adults (Rounds, 1990; Sagiv, 2002), university students (Berings, De Fruyt, \& Bouwen, 2004; Duffy, Borges, \& Hartung, 2009) and high school adolescents (Hirschi, 2008; Lapan, Hinkelman, Adams, \& Turner, 1999).

Sagiv (2002) examined the clients' vocational interests and values in his study conducted with 97 clients who were receiving career counseling. Sagiv's (2002) study findings revealed that conventional personality type correlated positively with the security, conformity and tradition values. Enterprising personality type correlated positively with power and achievement values. Social personality type also correlated positively with benevolence value. Finally, artistic personality type correlated positively with self-direction and universalism values. Berings, Fruyt and Bouwen's 
(2004) study on 178 students studying commercial engineering and commercial sciences examined the relationship between social and enterprising vocational interests and vocational values, and personality traits. The study results determined that the values of Influence and Team was a significant predictor of preference for entrepreneurial professions, whereas those who were interested in social vocations paid less attention to Earnings vocational value.

Hirschi (2008), in his study on Swedish adolescents, examined the relationship between five factor personality traits, vocational personality types, vocational values and efficacy beliefs of nine and eleventh grade students. The study findings put forth that the students with high social and artistic personality type scores had high social vocational value scores, and the students with high enterprising personality type scores had high respectability value scores were high. In another study on vocational interests, Duffy, Borges and Hartung (2009) examined of medical faculty students' personality traits and vocational interest areas' predictive power of their vocational values. The study results determined that personality traits and vocational interests were significant predictors of vocational values.

When the samples of studies conducted on the relationship between vocational personality types and vocational values were examined, it was found that there were limited number of studies on this subject, particularly conducted with high school students. In addition, there was no study where the relationship between two variables was investigated amongst adolescents in Turkey. Considering the limited number of studies carried out on adolescent students in the literature, it was believed that examining the relationship between vocational personality types and vocational values of high school students for whom career choice and career formation is of vital importance during this period would contribute to the related literature. Hence, the present study aimed to examine the relationship between vocational personality types and vocational values.

\section{Method}

\subsection{Research Design}

The aim of this study is to examine the relationship between high school students' vocational personality types and vocational values. Accordingly, the study employed the correlational design. Correlational studies are the studies examining the relationship between two or more variables without any intervention (Fraenkel, Wallen, \& Hyun, 2012).

\subsection{Participant and Sampling Procedures}

The study universe was comprised of high school seniors going to schools in the Niğde city center. It was decided that the study should be carried out with high school senior students because they were in the stage of choosing a higher education program. The schools were divided into two groups as Anatolian High Schools and Vocational High Schools by using cluster sampling method. Six high schools, three of which were Anatolian high schools and the other three vocational high schools, were randomly selected for the study, and the data were collected from 488 randomly selected senior students from these six high schools. In order to collect data, necessary permissions were obtained from the related institutions. Then, the researcher visited the schools in the sample and collected data from the students who volunteered to participate in the research. Table 1 shows the descriptive information regarding the sample group.

Table 1. Descriptive information regarding the sample group

\begin{tabular}{llll}
\hline & & N & \% \\
\hline Sex & Female & 259 & 53 \\
& Male & 229 & 47 \\
\hline \multirow{2}{*}{ School Type } & Anatolian High & 277 & 57 \\
& Vocational High & 211 & 43
\end{tabular}

According to Table 1, while 53\% of the students in the study sample were female (259), 47\% were male (229). Also, 57\% of the students were enrolled at Anatolian High Schools (277), whereas 43\% were enrolled at Vocational High Schools (211).

\subsection{Data Collection Tools}

Within the scope of the study, Vocational Value Inventory (Atli, 2012), Occupational Personality Types Inventory (Atli, \& Keldal, 2017) and Personal Information Form were used.

Vocational Value Inventory: The inventory was developed by Atli (2012) to measure the vocational values of high school students. The inventory consists of 35 items and nine dimensions. These sub-dimensions are friendship, teamwork, use of physical characteristics, vocational health, leadership, freedom, financial gain, creativity and benevolence. In order to determine the individuals' participation levels in each item in the inventory, a 9-point Likert-type scale was used ranging from (1) Strongly Disagree to (9) Strongly Agree. The calculation of the internal 
consistency coefficient was analyzed using test-retest reliability methods. Cronbach $\alpha$ coefficients of the sub-dimensions of the inventory were calculated between .70 and .83 . The correlation values regarding the test-retest reliability were between .61 and .82 . In the reliability study conducted within the scope of this study, Cronbach $\alpha$ coefficients were found between .67 and .83 .

Occupational Personality Types Inventory: The Occupational Personality Types Inventory was developed by Atli and Keldal (2017) based on Holland's typology theory. The inventory consists of six dimensions (realistic, enterprising, investigative, social, artistic, conventional) and 30 items, each of which aims to identify occupational personality types. a 9-point Likert-type scale was used ranging from (1) Strongly Disagree to (9) Strongly Agree to determine the level of participation of individuals in each item in the inventory. The calculation of the internal consistency coefficient was analyzed using test-retest reliability methods. Cronbach $\alpha$ coefficients of the sub-dimensions of the inventory were calculated between .72 and .85 . The correlation values regarding the test-retest reliability were between .71 and .80 . In the reliability study conducted within the scope of this study, Cronbach $\alpha$ coefficients were found between .71 and .82 .

Personal Information Form: Personal information form contains questions regarding demographic information.

\subsection{Data Analysis}

The study data was analyzed using the SPSS 23.0 program. In the study, the relationship between vocational personality types and vocational values was examined with canonical correlation analysis. The aim of the canonical correlation is to analyze the relationship between two sets of variables. One of these two sets of variables can be considered as dependent variable and the other as independent variable. The researcher finds the opportunity to obtain data about whether there is a relationship between the two variables and the nature of this relationship (Tabachnick, \& Fidell, 2013). In this study, one of the sets consists of vocational personality types (realistic, enterprising, investigative, social, artistic, conventional), while the other set consists of vocational values friendship, teamwork, use of physical characteristics, vocational health, leadership, freedom, financial gain, creativity and benevolence).

Before data analysis, the conditions and assumptions that must be met were checked. First, data entries and missing data were checked, and no error in data entries was found. Then, missing data were checked, and it was seen that the missing data did not exceed 5\%. In order to interpret a variable set, the variable to person ratio must be $1 / 20$ (Stevens, 2009). Before the canonical correlation, the adequacy of the sample size was checked, and it was fund that the assumption regarding the sample size (variable/person) was met. Later, the data were converted to z-points, and after the control of z-points, the data in the extreme values were deleted, and the subsequent analyzes were carried out with 485 data. The multivariate extreme values were checked by mahalanobis distance test, and no multivariable extreme values were found. In addition, linearity, normality and equivalence assumptions were checked and it was observed that the assumptions were met in the data set.

\section{Results}

In this section, findings obtained as a result of the canonical correlation analysis are presented. The first step of canonical correlation analysis is to examine the results of multivariate significance test to test whether the canonical model is statistically significant (Sherry, \& Henson, 2005). The results of the multivariate significance test for the significance of the model are presented in Table 2.

Table 2. Results of multivariate significance test

\begin{tabular}{lccccc}
\hline Test Name & Value & Approximation & $\begin{array}{c}\text { Hypothesis } \\
\text { sd }\end{array}$ & $\begin{array}{c}\text { Error } \\
\text { sd }\end{array}$ & $\boldsymbol{F}$ \\
\hline Wilks' Lambda & .33 & 10.81 & 54 & 2401.1 & .000 \\
\hline
\end{tabular}

$\mathrm{S}=6 \mathrm{M}=1 \mathrm{~N}=234$

The data obtained in Table 2 show that the canonical model [Wilks ' $\lambda=.33, F(54,2401.1)=10.81, \mathrm{p}<.001$ ] was statistically significant. However, the significance of these tests does not give any information about the strength of the relationship obtained. Even the smallest $\mathrm{F}$ values may be significant in studies with a high number of participants. Therefore, it is important to examine the effect size as well as the significance of the model. On this issue, the Wilks $\lambda$ value, which is called the reverse effect size, is used. This value represents the unexplained variance between canonical variables. In this respect, " $1-\lambda$ " value shows the common variance amount that canonical variables share and can be interpreted as $R^{2}$ value in the regression analysis (Çetin, İlhan, \& Yllmaz, 2014). In this study, "1- $\lambda$ " value was calculated as .67 for the Wilks $\lambda$ value. According to this result, it can be said that the common variance shared between vocational personality type and vocational value data sets was $67 \%$.

In addition to whether the model obtained in canonical correlation analysis is statistically significant or not, each 
canonical function should be examined separately to determine whether they are significant or not. To determine which canonical functions are significant, canonical functions' eigenvalues and canonical correlation values should be examined (Sherry, \& Henson, 2005). The findings regarding the eigenvalue and canonical correlation values are given in Table 3.

Table 3. Eigenvalue and canonical correlation values

\begin{tabular}{cccc}
\hline & Eigenvalue & Canonical Correlation & Canonical Correlation Square \\
\hline 1 & .80 & .67 & .44 \\
2 & .42 & .54 & .30 \\
3 & .12 & .33 & .11 \\
\hline
\end{tabular}

According to the findings in Table 3, there were three significant canonical function. The canonical correlation coefficient of the first canonical function was .67. Therefore, vocational personality type and vocational value data sets share $44 \%$ variance in the first canonical function. The correlation coefficient of the second canonical function was .54. In the second canonical function, the variance shared between the data sets was $30 \%$. The canonical correlation coefficient for the third canonical function was .33. Hence, the variance shared between vocational personality type and vocational value data sets in the third canonical function was $11 \%$.

In the interpretation of the canonical correlation analysis, variables in the sets, correlation coefficients (loads) between the canonical variate pars and standardized canonical coefficients are used. When evaluating the contribution of a variable, these two coefficients are addressed together, and it is assumed that the variables with a correlation greater than .30 have a significant load on the related component (Özer, \& Altun, 2011). The relationships between the variable sets for each canonical function are given in Table 4.

Table 4. Correlation coefficients between canonical variables, and dependent and independent variables sets, standardized canonical coefficients, explained variance and redundancy values

\begin{tabular}{|c|c|c|c|c|c|c|}
\hline \multirow[t]{2}{*}{ Variables } & \multicolumn{2}{|c|}{$\mathbf{1}^{\text {st }}$ Canonical Variable } & \multicolumn{2}{|c|}{$2^{\text {nd }}$ Canonical Variable } & \multicolumn{2}{|c|}{$3^{\text {rd }}$ Canonical Variable } \\
\hline & Correlation & $\begin{array}{c}\text { Standard } \\
\text { Coefficient }\end{array}$ & Correlation & $\begin{array}{c}\text { Standard } \\
\text { Coefficient }\end{array}$ & Correlation & $\begin{array}{c}\text { Standard } \\
\text { Coefficient }\end{array}$ \\
\hline \multicolumn{7}{|l|}{$\begin{array}{l}\text { Set-1(Vocational } \\
\text { Personality Types) }\end{array}$} \\
\hline Realistic & -.63 & -.53 & -.72 & -.59 & -.22 & -.65 \\
\hline Enterprising & -.37 & -.22 & -.54 & -.08 & .39 & .42 \\
\hline Investigative & -.07 & -.06 & -.57 & -.21 & .38 & .28 \\
\hline Social & .74 & .64 & -.60 & -.45 & -.17 & -.07 \\
\hline Artistic & .26 & .05 & -.51 & -.06 & .52 & .65 \\
\hline Conventional & .38 & .23 & -.54 & -.19 & .35 & .35 \\
\hline Explained variance & .20 & & .28 & & .12 & \\
\hline Redundancy & .09 & & .10 & & .01 & \\
\hline \multicolumn{7}{|l|}{$\begin{array}{l}\text { Set- } 2 \\
\text { (Vocational Values) }\end{array}$} \\
\hline Friendship & .68 & .22 & -.50 & -.18 & .13 & .05 \\
\hline Teamwork & .42 & .03 & -.53 & -.02 & -.06 & -.39 \\
\hline Use of Phy. Chr. & -.46 & -.49 & -.82 & -.68 & -.02 & -.15 \\
\hline Leadership & .12 & -.05 & -.48 & -.14 & .26 & .13 \\
\hline Freedom & .12 & .02 & -.28 & -.05 & .19 & -.30 \\
\hline Financial Gain & .17 & -.05 & -.21 & .08 & .46 & .20 \\
\hline Occp. health & .45 & .19 & -.19 & .13 & .72 & .81 \\
\hline Benevolence & .82 & .66 & -.51 & -.28 & -.13 & -.42 \\
\hline Creativity & .05 & -.10 &.-66 & -.28 & .48 & .54 \\
\hline Explained Variance & .21 & & .35 & & .12 & \\
\hline Redundancy & .09 & & .08 & & .01 & \\
\hline
\end{tabular}

According to Table 4, the mean variance ratios of the first, second and third canonical variables obtained from the vocational personality types set within their own sets were $.20, .28$ and 12 , respectively. Also, the mean variance ratios (redundancy) explained in the vocational values set were .09, .10 and .01, respectively. On the other hand, the mean variance ratios of the first, second and third canonical variables obtained from the vocational personality types set within their own sets were.21, .35 and .12 , respectively. Also, the mean variance ratios (redundancy) explained in the vocational values set were $.09, .08$ and .01 , respectively. 
According to these results, it can be said that the first and second canonical variables are more effective in explaining the variance in the vocational value set than the vocational personality type set. On the other hand, it can be stated that the third canonical variable does not show a difference between the ratios explain the variance regarding the two data sets. Correlation coefficients of the variables in the data sets are given in Figures 2, 3 and 4.

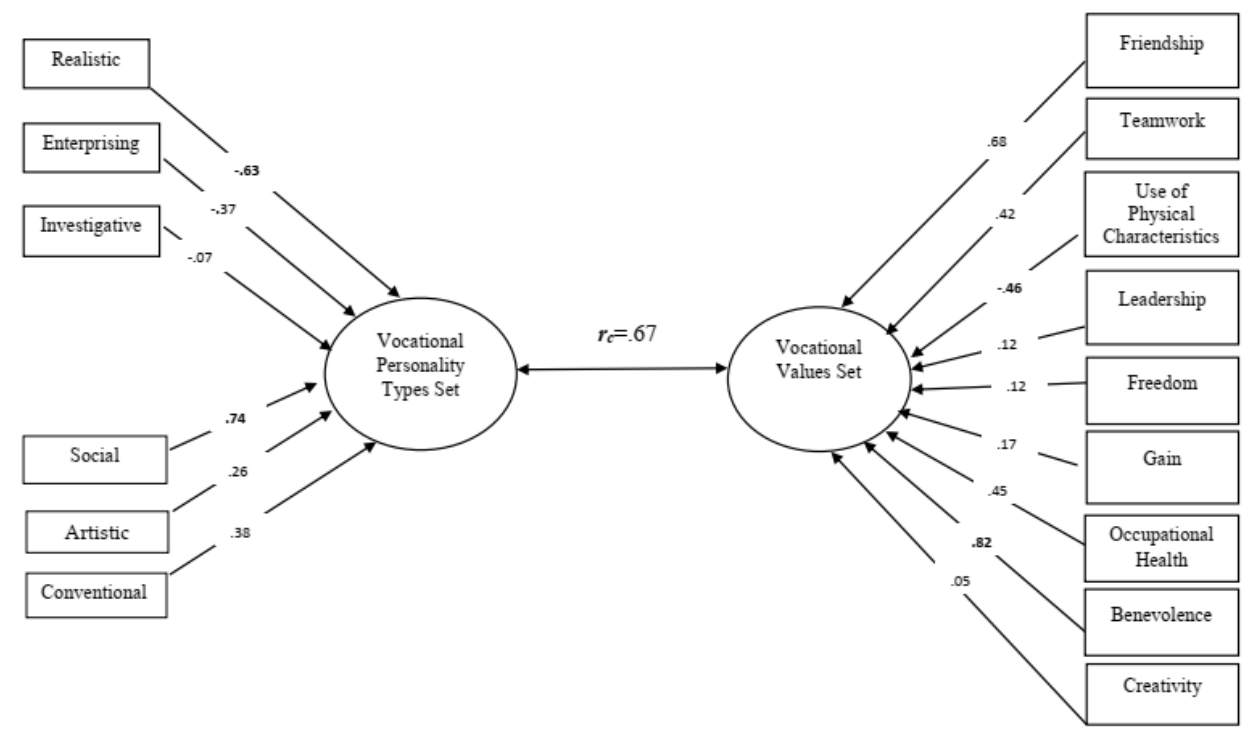

Figure 2. Correlation values of the $1^{\text {st }}$ canonic function between vocational personality types and vocational values

In Figure 2, when the data of the first canonical variable were evaluated by taking the correlation coefficient cut-off point as .30, Social (r: .74), Realistic (r: -.63), Enterprising (r: -.37) and Conventional (r: -.38) personality type variables from the vocational personality type set were found to be related to the first canonical variable. However, when these variables were evaluated together with standardized coefficients, the findings showed that the variables contributing to the first canonical variables were social and realistic personality type variables, respectively. In addition, when the variables of vocational value set was evaluated by taking the standardized coefficients into consideration, the findings demonstrated that benevolence (r: .82) and use of physical characteristics (r: -.46) vocational value variables contributed to the fist canonic variable.

Findings related to the first canonical variable put forth that the individuals with high social personality type scores but with low realistic personality type scores gave importance to benevolence vocational value but did not give importance to use of physical characteristics vocational value.

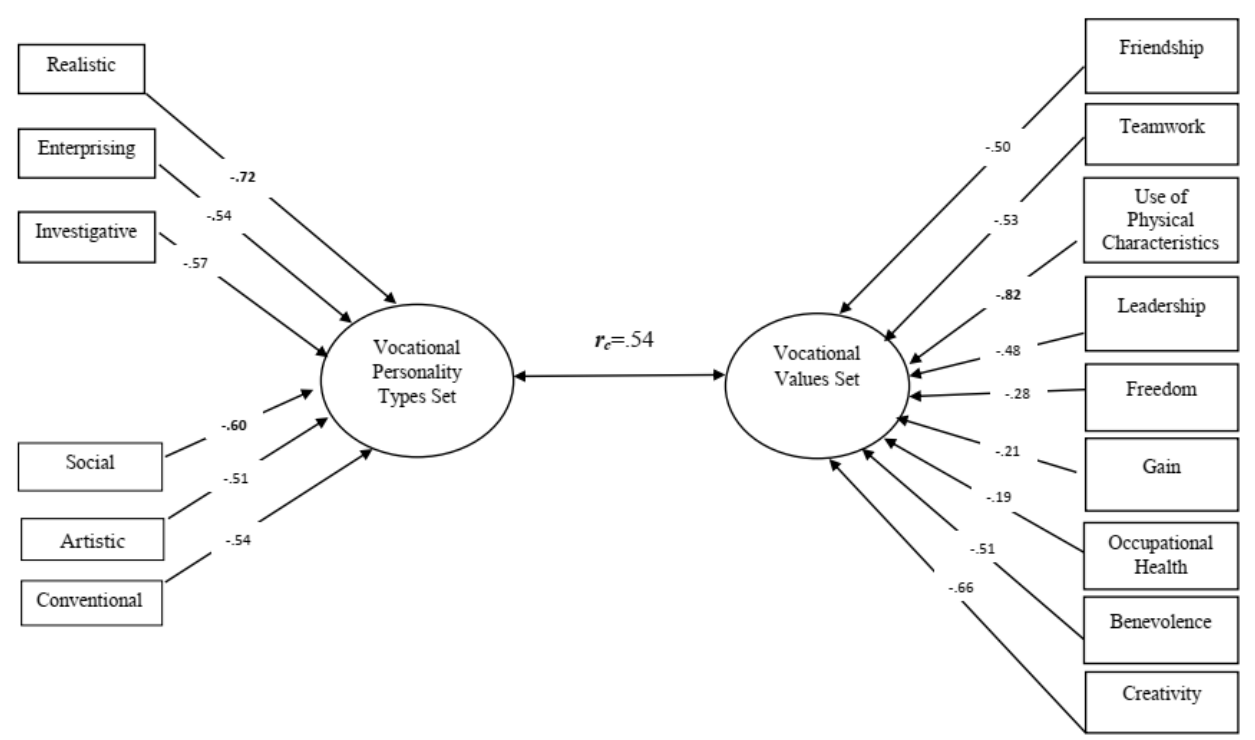

Figure 3. Correlation values of the $2^{\text {nd }}$ canonic function between vocational personality types and vocational values 
When the correlation values of the second canonical function presented in Figure 3 are evaluated together with standardized coefficients, Realistic (r:-.72) and Social (r:-.60) personality type variables contributed to the second canonic function of the vocational personality type set. In the vocational values set, the Use of Physical Characteristics (r:-.82) contributed to the second canonical function of the vocational values. This finding can be interpreted as those with low social and realistic personality type scores do not attach importance to the value of use of physical characteristics.

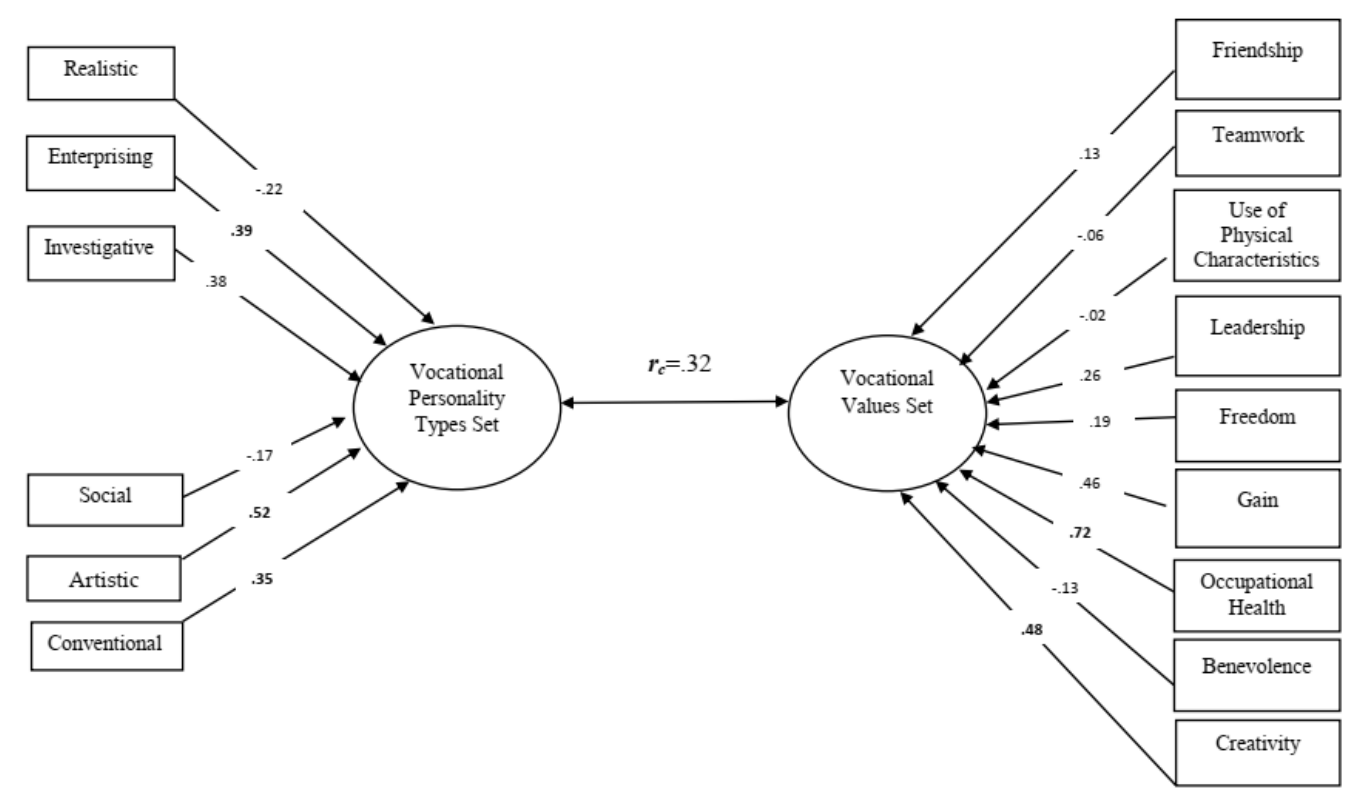

Figure 4. Correlation values of the $3^{\text {rd }}$ canonic function between vocational personality types and vocational values

When the correlation values of the third canonical function are evaluated together with standardized coefficients, Artistic (r: .52), Enterprising (r: .39) and Social (r:.35) personality type variables contributed to the third canonic function of the vocational personality type set. In the vocational values set, occupational health (r: .72) and Creativity (r: .48) contributed to the third canonical function of the vocational values. This finding demonstrated that individuals with high artistic, enterprising and social personality type scores attach importance to the values of vocational health and creativity.

\section{Discussion}

In this study, it was aimed to examine the relationship between high school students' vocational personality types and occupational values. The relationship between the two variables was examined by canonical correlation analysis technique. At the end of the analysis done, three canonical functions regarding the relationship between vocational personality types and vocational values were obtained.

The canonical correlation coefficient of the first canonical function was .67. Accordingly, vocational personality types and vocational value data sets shared $44 \%$ variance in the first canonical function. When the canonical loads of data sets were evaluated together with standardized coefficients, the findings put forth that social and realistic personality type variables from the vocational personality types contributed to the first canonical function, whereas benevolence and use of physical characteristics variables from the vocational value sets contributed also to the first canonical function. When this finding was interpreted together with correlation coefficient and other structural coefficients, the individuals with high social personality type scores but with low realistic personality type scores attached importance to benevolence vocational value but did not attach importance to use of physical characteristics vocational value. This finding is consistent with the social personality type and vocational environments appropriate to the social personality type mentioned in Holland (1997) typology. In addition, the results of Sagiv's (2002) study that examined the relationship between vocational interests and vocational values support the present study's findings. As a result of this research, a positive significant relationship was also found between social personality type and benevolence vocational value. Another finding supporting this finding is Sun's (2011) study findings. In his doctoral dissertation, he examined personality traits, vocational interests and values within the framework of university students' life purposes. He determined that there was a positive significant relationship between social personality type and benevolence value. Supported by other different study results, this finding is believed to be important in providing a source of information about the occupational value perceptions of experts working with clients with high level of social interest. 
In the second canonical function, the canonical correlation value, which is not taken into account in the first canonical function and which shows the maximum relationship between the two canonical variables, is calculated. The correlation coefficient of the second canonical function was .54. In the second canonical function, the variance shared between the data sets was $30 \%$. When the canonical loads of the data sets were evaluated together with standardized coefficients, realistic and social personality type variables contributed to the second canonic function of the vocational personality type set, whereas in the vocational values set, the use of physical characteristics contributed to the second canonical function of the vocational values. When evaluated with correlation values and other structural coefficients, this finding revealed that those with high social and realistic personality type scores do not attach importance to the value of use of physical characteristics.

In Holland (1997) typology, while realistic personality type and vocational environments regarding realistic personality type expect activities from individuals about the use of physical characteristics, social personality type and vocational environment regarding this personality type do not expect activities about from individuals on the use of physical characteristics Instead, the social personality type's vocational environment demands activities from people to help people and interact with them to solve their problems. When the findings obtained from the second canonical function are evaluated within this framework, the fact that the social personality type does not give importance to the use of physical characteristics is consistent with the literature, whereas the fact that the realistic personality type does not give importance to the use of physical characteristics is not constant with the literature regarding vocational personality types. In line with this study finding, in the sample of the future studies to be conducted on the subject, it is believed that it would be beneficial to diversify the vocational high schools and collect data from different grade levels.

In the third canonical function, the canonical correlation value, which is not taken into account in the first canonical function and which shows the maximum relationship between the two canonical variables, was calculated. The correlation coefficient of the third conical function was .33. In the third canonical function, the variance shared between the data sets was $11 \%$. When the correlation values of the third canonical function are evaluated together with standardized coefficients, artistic, enterprising, and social personality type variables were seen amongst the vocational personality type set, whereas Occupational health and Creativity were seen amongst the vocational values set. When the correlation values and structural coefficients were interpreted, individuals with high artistic, enterprising and social personality type scores attach importance to the values of occupational health and creativity. While this finding is consistent with the literature on vocational personality types (Holland, \& Rayman, 1986; Holland, 1997) in a certain way, it is not consistent with the literature in other ways. While the finding that the artistic and enterprising vocational personality type has creativity values shows parallelism with the literature, the finding that these personality types give importance to occupational health professional values does not show parallel results with the related literature.

It is believed that the study results will be significant in contributing to the literature on the relationship between high school students' vocational personality types and professional values. In addition, the findings of the study can be a guide for vocational guidance and career counseling services in schools for students with career indecisions. Furthermore, it was decided that the study should be carried out with high school senior students because they were in the stage of choosing a higher education program. On the other hand, this is an important limitation for the study due to the lack of data collection from different class levels. When the generalizability problem is taken into consideration, the collection of data from students at different grade levels can be presented as a recommendation for researchers.

\section{References}

Ackerman, P. L., \& Beier, M. E. (2003). Intelligence, personality, and interests in the career choice process. Journal of Career Assessment, 11(2), 205-218. https://doi.org/10.1177/1069072703011002006

Adıgüzel, O., \& Erdoğan, A. (2014). Anne roe ve holland'ın kişilik kuramları ile shein'in kariyer değerlerinin içerik analizi yöntemiyle değerlendirilmesi [Anne roe and holland's personality theories and shein's career anchors assessment with content analysis method]. Journal of Alanya Faculty of Business/Alanya Isletme Fakültesi Dergisi, 6(3), 15-25

Anderson, M. Z., Tracey, T. J., \& Rounds, J. (1997). Examining the invariance of Holland's vocational interest model across gender. Journal of Vocational Behavior, 50(3), 349-364. https://doi.org/10.1006/jvbe.1996.1550

Atli, A. (2012). Lise öğrencilerinin mesleki değerlerinin incelenmesi (Unpublished doctoral dissertation). İnönü Üniversitesi, Malatya.

Atli, A., \& Kaya, A. (2016). Lise öğrencilerinin mesleki değerleri [An analysis of high school students' career values]. Mersin University Journal of the Faculty of Education, 12(1). https://doi.org/10.17860/efd.78099

Atli, A., \& Keldal, G. (2017). Mesleki kişilik tipleri envanterinin geliştirilmesi [Development of occupational personality types inventory]. Eskişehir Osmangazi Üniversitesi Sosyal Bilimler Dergisi, 18(1), 73-93. 
https://doi.org/10.17494/ogusbd.330743

Batur, H. Z. (2014). Schein'in kariyer değerleri perspektifinde öğrencilerin kariyer tercihlerini etkileyen faktörler üzerine bir araştırma: Isparta ili fen lisesi statüsündeki okullar örneği. (Unpublished Master Thesis). Süleyman Demirel Üniversitesi, Isparta.

Bayrakdar, M. (2009). Lise son sınıf öğrencilerin dĕger tercihleri ve meslek tercihleri arasındaki ilişki. (Unpublished Master Thesis). Marmara Üniversitesi, İstanbul.

Berings, D., De Fruyt, F., \& Bouwen, R. (2004). Work values and personality traits as predictors of enterprising and social vocational interests. Personality and Individual Differences, 36(2), 349-364. https://doi.org/10.1016/S0191-8869(03)00101-6

Betsworth, D. G., \& Fouad, N. A. (1997). Vocational interests: A look at the past 70 years and a glance at the future. The Career Development Quarterly, 46, 23-47. https://doi.org/10.1002/j.2161-0045.1997.tb00689.x

Beutell, N. J., \& Brenner, O. C. (1986). Sex differences in work values. Journal of Vocational Behavior, 28(1), $29-41$. https://doi.org/10.1016/0001-8791(86)90037-0

Bozgeyikli, H., Derin, S., \& Toprak, E. (2016). Üniversite öğrencilerinin mesleki değer algıları [University Students' Career Values Perceptions]. International Journal Contemporary Educational Studies, 2(1), 139-156.

Brown, D. (2003). Career Information, Career Counseling and Career Development. ABD: Pearson Education, Inc.

Brown, D., \& Associates (Eds.). (2002). Career choice and development (4th ed.). San Francisco, CA: Jossey-Bass

Burke, R. J. (1994). Career and life values and expectations of university business students. Psychological Reports, 75(1), 147-160. https://doi.org/10.2466/pr0.1994.75.1.147

Çetin, B., İlhan, M., \& Yılmaz, F. (2014). Olumsuz değerlendirilme korkusu ve akademik risk alma arasındaki ilişkinin kanonik korelasyonla incelenmesi [An 1nvestigation of the relationship between the fear of receiving negative criticism and of taking academic risk through canonical correlation analysis]. Kuram ve Uygulamada Eğitim Bilimleri Dergisi, 14(1), 135-158.

Demircioğlu, H. (2004). Lise öğrencilerinin algılanmış yetenek, ilgi ve değerleri üzerinde grupla mesleki psikolojik danışmanın etkisi (Unpublished Master Thesis). Gazi Üniversitesi, Ankara.

Deniz, K. Z. (2009). Mesleki Alan İlgi Envanteri (MAİ) Geliştirme Çalışması [Occupatıonal field ınterest ınventory (OFII) development study]. Yüzüncü Yll Üniversitesi Eğitim Fakültesi Dergisi, 6(1). 288-310.

Dick, T. P., \& Rallis, S. F. (1991). Factors and influences on high school students' career choices. Journal for Research in Mathematics Education, 22(4), 281-292. https://doi.org/10.2307/749273

Duffy, R. D., Borges, N. J., \& Hartung, P. J. (2009). Personality, vocational interests, and work values of medical students. Journal of Career Assessment, 17(2), 189-200. https://doi.org/10.1177/1069072708329035

Farth, J. L., Leong, F. T., \& Law, K. S. (1998). Cross-cultural validity of Holland's model in Hong Kong. Journal of vocational behavior, 52(3), 425-440. https://doi.org/10.1006/jvbe.1997.1631

Ferreira, J. A. A., \& Hood, A. B. (1995). The development and validation of a Holland-type Portuguese Vocational Interest Inventory. Journal of Vocational Behavior, 46(2), 119-130. https://doi.org/10.1006/jvbe.1995.1008

Fraenkel, J. R., Wallen, N. E., \& Hyun, H. H. (2012). How to design and evaluate research in education (Vol. 8). New York: McGraw-Hill.

Gottfredson, L. S., \& Richards Jr, J. M. (1999). The meaning and measurement of environments in Holland's theory. Journal of Vocational Behavior, 55(1), 57-73. https://doi.org/10.1006/jvbe.1999.1697

Hartung, P. J. (2006). Values. In J.H. Greenhause \& G. A. Callanan (Eds.), Encyclopedia of Career Development. (843-846). London: Sage Publications.

Hirschi, A. (2008). Personality complexes in adolescence: Traits, interests, work values, and self evaluations. Personality and Individual Differences, 45(8), 716-721. https://doi.org/10.1016/j.paid.2008.07.018

Hogan, R., \& Blake, R. (1999). John Holland's vocational typology and personality theory. Journal of Vocational Behavior, 55(1), 41-56. https://doi.org/10.1006/jvbe.1999.1696

Holland, J. L., \& Rayman, J. R. (1986). "Self-Directed Search". İn (Edt. W. Bruce Walsh, \& Samuel H. Osipow). Advances in Vocational Psychology: Volume 1: The Assessment of interests, 55.

Holland, J. L. (1997). Making vocational choice: A theory of vocational personalities and work environments (3 ${ }^{\text {rd }}$ ed.). Lutz, FL: Psychological Assessment Resources. 
Koç, B. (2006). Illgi ölçümlerinin madde sayısının azaltılması ve yaş ranjının genişletilmesine yönelik bir geçerlik-güvenirlik çalı̧̧ması. (Unpublished Master Thesis). Çukurova Üniversitesi Sosyal Bilimler Enstitüsü, Adana.

Koca, A. İ. (2009). Üniversite öğrencilerinin değerleri ve bireysel özellikleri ile kariyer tercihleri arasindaki ilişki: Çukurova Üniversitesi'nde bir araştırma. (Unpublished Master Thesis). Çukurova Üniversitesi, Adana.

Koca, A. İ. (2010). Kariyer seçiminde kariyer değerleri ile demografik faktör ilişkisi: Çukurova Üniversitesi'nde bir araştırma [The relationship of students' career preferences to personal values and demographic characteristics at cukurova university]. Çukurova Üniversitesi İktisadi ve İdari Bilimler Fakültesi Dergisi, 14(1), 56-70.

Kuzgun, Y. (2009). Meslek rehberliği ve danışmanlı̆̆ına girişs. Nobel Yayın Dağıtım.

Lapan, R. T., Hinkelman, J. M., Adams, A., \& Turner, S. (1999). Understanding rural adolescents' interests, values, and efficacy expectations. Journal of Career Development, 26(2), 107-124. https://doi.org/10.1177/089484539902600202

Larson, L. M., \& Borgen, F. H. (2002). Convergence of vocational interests and personality: Examples in an adolescent gifted sample. Journal of Vocational Behavior, 60(1), 91-112. https://doi.org/10.1006/jvbe.2001.1821

Lewis, M. M., \& Hardin, S. I. (2002). Relations among and between career values and Christian religious values. Counseling and Values, 46(2), 96. https://doi.org/10.1002/j.2161-007X.2002.tb00280.x

Logue, C. T., Lounsbury, J. W., Gupta, A., \& Leong, F. T. (2007). Vocational interest themes and personality traits in relation to college major satisfaction of business students. Journal of Career Development, 33(3), 269-295. https://doi.org/10.1177/0894845306297348

Moore, C. A. S. (2006). Career values of college students: An analysis by generation, gender, race, and family diversity (Doctoral dissertation, Capella University).

Mount, M. K., Barrick, M. R., Scullen, S. M., \& Rounds, J. (2005). Higher-order dimensions of the big five personality traits and the big six vocational interest types. Personnel Psychology, 58(2), 447-478. https://doi.org/10.1111/j.1744-6570.2005.00468.x

Murphy, S. A. (2000). A study of career values by generation and gender (Doctoral dissertation, Fielding Institute).

Nordvik, H. (1996). Relationships between Holland's vocational typology, Schein's career anchors and Myers-Briggs' types. Journal of Occupational and Organizational Psychology, 69(3), 263-275. https://doi.org/10.1111/j.2044-8325.1996.tb00614.x

Owen, F. K., Acar, T., Demir, Y., Haskan, Ö., \& Kabalcı, T. (2009). Mesleki rehberlik kariyer danışmanlığında kart sıralama tekniği: mesleki değerler ile ilgili bir çalışma [Card sort technique in vocational guidance/career counseling: pilot study about career values]. İn̈̈nü Üniversitesi Ĕgitim Fakültesi Dergisi, 10(2), 53-70.

Özer, A. \&Altun, E. (2011). Üniversite öğrencilerinin akademik erteleme nedenleri [The reasons for academic procrastination among university student]. Mehmet Akif Ersoy Üniversitesi Eğitim Fakültesi Dergisi, 1(21), 45-72.

Perkmen, S., \& Tezci, E. (2015). Holland teorisinin 1şı̆̆ında meslek kişiliğinin ölçülmesi [Measurement of Vocational Personality Theory in Light of Holland]. Necatibey Ĕgitim Fakültesi Elektronik Fen ve Matematik Eğitimi Dergisi, 9(1). https://doi.org/10.17522/nefefmed.57385

Rounds, J., \& Jin, J. (2012). Nature, importance, and assessment of needs and values. Career development and counseling: Putting theory and research to work, 417-448.

Rounds, J. B. (1990). The comparative and combined utility of work value and interest data in career counseling with adults. Journal of Vocational Behavior, 37(1), 32-45. https://doi.org/10.1016/0001-8791(90)90005-M

Rounds, J. B., Davison, M. L., \& Dawis, R. (1979). The fit between Strong-Campbell Interest Inventory general occupational themes and Holland's hexagonal model. Journal of Vocational Behavior, 15(3), 303-315. https://doi.org/10.1016/0001-8791(79)90027-7

Ryan, J. M., Tracey, T. J., \& Rounds, J. (1996). Generalizability of Holland's structure of vocational interests across ethnicity, gender, and socioeconomic status. Journal of Counseling Psychology, 43(3), 330. https://doi.org/10.1037/0022-0167.43.3.330

Sagiv, L. (2002). Vocational interests and basic values. Journal of Career Assessment, 10(2), 233-257. https://doi.org/10.1177/1069072702010002007

Savickas, M. L. (2013). Career Construction Theory and Practice. Brown, S. D., \& Lent, R. W. (Eds.). (2013). Career development and counseling: Putting theory and research to work. John Wiley \& Sons. 
Schein, E. H. (2006). Career Anchor. In J.H. Greenhause\&G.A. Callanan (Eds.), Encyclopedia Of Career Development (63-69). London: Sage Publications.

Sherry, A., \& Henson, R. K. (2005): Conducting and interpreting canonical correlation analysis in personality research: A user-friendly primer. Journal of Personality Assessment, 84(1), 37-48. https://doi.org/10.1207/s15327752jpa8401_09

Sortheix, F. M., Dietrich, J., Chow, A., \& Salmela-Aro, K. (2013). The role of career values for work engagement during the transition to working life. Journal of Vocational Behavior, 83(3), 466-475. https://doi.org/10.1016/j.jvb.2013.07.003

Stevens, J. (2009). Applied multivariate statistics for the social sciences. New Jersey: Lawrence Erlbaum Associates

Sun, J. T. (2011). Major life goals of college students: An investigation of personality traits, vocational interests, and values (Doctoral dissertation, University of Illinois at Urbana-Champaign).

Tabachnick, G. B., \& Fidell, L. S. (2013). Using multivariate statistics (6. bs.). London: Pearson.

Tokar, D. M., \& Swanson, J. L. (1995). Evaluation of the Correspondence between Holland's Vocational Personality Typology and the Five-Factor Model of Personality. Journal of Vocational Behavior,46(1), 89-108. https://doi.org/10.1006/jvbe.1995.1006

Tracey, T. J., \& Rounds, J. B. (1993). Evaluating Holland's and Gati's vocational-interest models: A structural meta-analysis. Psychological Bulletin, 113(2), 229. https://doi.org/10.1037/0033-2909.113.2.229

Weinrach, S. G. (1996). The phychological and vocational interest patterns of Donald Super and John Holland. Journal of Counseling and Development: JCD, 75(1), 5. https://doi.org/10.1002/j.1556-6676.1996.tb02309.x

Yılmaz, O. (2011). Mesleki ilgi envanterinin geliștirilmesi. (Unpublished Master Thesis). Hacettepe Üniversitesi, Ankara.

\section{Copyrights}

Copyright for this article is retained by the author(s), with first publication rights granted to the journal.

This is an open-access article distributed under the terms and conditions of the Creative Commons Attribution license which permits unrestricted use, distribution, and reproduction in any medium, provided the original work is properly cited. 